\title{
ZDAŘILÁ INOVACE STANDARDNÍ UČEBNICE HOSPODÁŘSKÉ POLITIKY
}

\section{Milan Žák, Petr Vymětal*}

\section{Christiana Kliková, Igor Kotlán a kol.: Hospodářská a sociální politika}

Ostrava: Vysoká škola sociálně správní, 2019. 5. vydání. 388 stran.

ISBN 978-80-87291-23-8.

Zhruba po šesti letech se vysokoškolským studentům dostává do rukou výrazně přepracovaná učebnice hospodářské politiky známé autorské dvojice Christiana Kliková, Igor Kotlán, tentokrát v doplněné verzi, a to nejen o autory, ale i v doplněném a rozšířeném textu. Zde vyniká na první pohled výrazná samostatná kapitola o sociální politice, která se svým způsobem i významem dostává i do názvu učebnice. I když se nejedná o učebnici zcela novou, oba hlavní autoři používají osvědčený základ z předchozích vydání, rozšiřrený o nová témata a problémy, je i nadále text určen spíše vysokoškolským studentům pokročilejší úrovně.

Učebnice doznala několika změn, které nelze hodnotit jinak než jako posun dobrým směrem. Na kapitolách se kromě dvou hlavních autorů či editorů podílejí další čtyři autoři, kteří se odborně zabývají tématy, o nichž píší. Zároveň některé kapitoly doznaly výraznějšího rozšíření - at' už jde o stručné subkapitoly týkající se Evropské unie, sociální politiky, a zejména části, jež se snaží využít poznatky politologie pro hospodářskou politiku. Navíc, výrazně obohacující a zajímavé jsou rozšiřující části paradigmatického a metodologického zakotvení popisované problematiky - hospodářské politiky. To vše také znamenalo, že muselo dojít k určité změně struktury knihy a mnohdy také ke slučování a vypouštění kapitol. Podívejme se na ně podrobněji a připojme k nim též kritický komentár̆, jež se od recenzentů očekává.

První kapitola je tou nejobsáhlejší a dá se říci, že představuje standardní instrumentárium hospodářské politiky, rozširřené o pohled na mezinárodní instituce a o problematiku Evropské unie (EU). I přes obsáhlost kapitoly by nebylo v př́ipadném dalším vydání na škodu možná ještě více rozšíriit text o koordinační mechanismy víceúrovňového vládnutí, zejména $v$ případě problematiky EU. Ocenit je naopak třeba snahu o rozšíŕení výkladu hospodářské politiky o politologické poznatky. Nepochybně je tento směr správný a recenzenti př́istup kvitují s povděkem, přesto může být tato část pro studenty poněkud obtížná - uvedené problémy mají spíše povahu seznamů, typologií a členění bez nějakého hlubšího vysvětlování příčin, důsledků a implikací pro samotnou problematiku. Tato kapitola je velmi členitá a obsahuje, podle našeho názoru možná zbytečně, deset dále ještě členěných subkapitol, byt' na druhé straně lze pochopit záměry autorů.

* Milan Žák (milan.zak@vsem.cz), Vysoká škola ekonomie a managementu; Petr Vymětal (petr.vymetal@vse.cz), Vysoká škola ekonomická v Praze, Fakulta mezinárodních vztahů. 
Druhá kapitola také patří do standardního penza znalostí, jež by podobná učebnice měla pokrývat, a to představení hlavních typů hospodářských politik. Třetí kapitola samostatně pojednává v 17 subkapitolách o sociální politice - po obsahové stránce ji lze přijmout bez závažnějších výhrad, protože jsou v ní zmíněny jak hlavní teoretické a historické koncepty sociální politiky, tak i nové trendy a současný stav jednotlivých oblastí této politiky. Možná je 17 subkapitol až přiliš a vzhledem k ostatním kapitolám knihy by jejich restrukturalizace možná dávala větší smysl. Čtvrtá kapitola nijak z původních, dříve vydaných textů nevybočuje a představuje hlavní specifika zaměřená na jednotlivé politiky - strukturální, regionální, ochrany životního prostředí, ochrany hospodářské soutěže. Pátá kapitola představuje v pojetí učebnice bezesporu novum a lze ji chápat jako vysoce podnětnou, leč jako vše nové, ještě „,neusazenou“. Navíc má dva rozměry, filozofický a modelový, které se ne vždy a ne přesně podařilo bezezbytku propojit. Na druhé straně je bezesporu výrazným pozitivem snaha zachytit obecný trend vývoje ekonomického myšlení, ale objem předkládaných informací se zdá příliš strohý a nepř́liš̌ zdařile strukturovaný.

Celkově lze knihu hodnotit jako dobrý pokus o nové rozšíření dosavadních textů, jež jsou na českých vysokých školách ekonomického zaměření používány po čtvrt století. Přesto se ale místy objevují nejasnosti, rovněž by se dal text „dotáhnout“" rozborem aktuálních problémů současné hospodářské politiky ve vybraných zemích světa, které většinou končí situací v 90. letech 20. století, takže nereflektují mj. problém brexitu. Trochu na škodu je i drobné př̌krývání některých pasáží textu popisujících problém společenského uspořádání s politologickou částí, která by navíc mohla pro zájemce odkazovat na další politologickou literaturu. $Z$ dílčích připomínek lze vyzdvihnout zásadní: volič medián je bez důkladného vysvětlení prezentován poněkud jinak, než bylo dosud běžné. Kriticky lze také poukázat třeba na skutečnosti, že se v některých částech učebnice př́iliš nevysvětlují problémy typu jak a proč stabilizační politika vychází z podstaty demokracie, proč Velká deprese stojí za zrodem moderní sociální politiky, nebo proč sociální politika vytvárí neefektivity a jaké. Místy se objevují také diskutabilní tvrzení typu: „Evropa se vzdaluje od světa“, nebo „Konsensus není optimálním řešením sporů.“ Vzhledem k výše zmíněnému, ne však př́liš přehnanému přeskupování kapitol lze konstatovat, že struktura jednotlivých kapitol byla v původních vydáních učebnice možná přece jen trochu přehlednější - ale to je věc názoru. Do budoucna by standardní výklad hospodářské politiky mohl pokrýt více témat, např́klad problematiku role zájmových skupin a lobbingu a zejména otázku institucionální analýzy a hodnocení kvality institucí, které se poslední dobou stávají jedním z populárních nástrojů hodnocení konkurenceschopnosti.

Závěrem je možno říci, že 5. vydání známé učebnice je povedené a moderní i v tom, že předkládá nová témata a že může výrazně zkvalitnit výuku předmětu hospodářské politiky. Otázkou však je, zda nenastal čas hledat jiné, třeba provokativnější pojetí celého kurzu hospodářské politiky včetně učebních textů. Vždyt' jednoduché schéma toho, jak ovlivňují rozhodovací autority ekonomický vývoj, spočívá pouze v regulaci a přerozdělování a k tomu se vážícím modelům delegování pravomocí. To by ovšem znamenalo zcela nový přístup k celé problematice, a kdo ví, zda by byl úspěšný. Učebnice má tedy stále šanci stát se nejvyhledávanějším učebním textem hospodářské politiky na českých vysokých školách. 